№ 28 (2019) стор. 39-57

The National Academy of Fine Arts and Architecture

Ukrainian Academy of Fine Art. Research and Methodology Papers

ISSN 2411-3034

Website: http://naoma-science.kiev.ua/

УДК 719:725.95(477.43-21Кам)

ORCID 0000-0003-2833-2827

DOI: https://doi.org/10.33838/naoma.28.2019.39-57

\title{
Ольга Пламеницька
}

кандидат архітектури, доцент plame@i.ua

\section{PONS ARCIS vs COLUMNAE TRAJANI*}

\begin{abstract}
Анотація. Висвітлено результати досліджень Замкового мосту у м. Кам'янці-Подільському, які дозволили заглибити хронологію його появи до перших століть нашої ери - епохи Траянових війн. Пошук архітектурно-конструктивних аналогів мосту привів до рельєфів Траянової колони в Римі (113 р. н.е.), аналіз яких дозволив, у свою чергу, спростувати загальноприйняту у світовій науці атрибуцію одного з рельєфів як зображення мосту через Дунай, зведеного у 103-105 рр. Аполлодором Дамаським під час війни проти Дакії. Авторка пропонує нову атрибуцію зображення цього мосту на колоні Траяна, а також робить спробу використання рельєфів колони для реконструкції вигляду мосту в Кам'янціПодільському на період перших століть нашої ери. Проведені дослідження дають підстави розглядати Середнє Подністер'я як контактну зону на межі праслов'янського та пізньоантичного світу.

Ключові слова: Кам'янець-Подільський, Замковий міст, дакійські війни, колона Траяна, Траянів міст, Аполлодор Дамаський.
\end{abstract}

\section{PONS ARCIS vs COLUMNAE TRAJANI}

Olga Plamenytska

Abstract. The article highlights the results of the research of the Castle Bridge in Kamianets-Podilsky, which allowed to deepen the chronology of the bridge's appearance back to the first centuries AD - the age of Trajan's Wars, and to insert the Castle Bridge into the context of fortification construction represented by the remains of the defense structures of the first centuries AD that were discovered in Kamianets-Podilsky in 1970-1990. The search of architectural and construction analogues of the bridge has led to the reliefs depicted on the Trajan's Column in Rome (113 AD), the analysis of which allowed, in its turn, to rebut the generally accepted by the world science attribution of one of the column's reliefs (XCIX) as the depiction of the Bridge over Danube, constructed in 103-105 by Apollodorus of Damascus during the Dacian Wars. The author suggest a new attribution of the image of this bridge on Trajan's Column, interpreting one of the well-known reliefs as the depiction of the bridge (LXXXVI). She argues in favor of the fact that the Bridge over Danube was completely made of stone and had no wooden arches. It became the first attempt of Apollodorus of Damascus, the author of the dome of Pantheon in Rome, to apply the Roman concrete in arches on large-scale constructions. Using the reliefs of the column as analogy allowed the author to reconstruct the image of the bridge in Kamyanets-Podilsky for the period of the first centuries AD. The conducted researches also give grounds to consider the Middle Dniester region as a contact zone on the border of early-Slavic and late-Antique worlds.

Keywords: Kamyanets-Podilsky, Castle Bridge, Dacian War, Trajan's Column, Trajan's Bridge, Apollodorus of Damascus.

Постановка проблеми. Витоки архітектури та урбаністики Русі в період, що передував злету Київської держави в X-XIII ст., практично не

\footnotetext{
* Замковий міст vs Колона Траяна (лат.).
}

вивчено. "Вибуховий” розвиток мурованої архітектури, який відбувся протягом лише двох десятиліть - від появи у 989-996 pр. Десятинної церкви до спорудження у 1011-1018 pp. Софійського собору - і поставив Київську Русь 
поряд з найпотужнішими державами Європи, досі не має аргументованих пояснень. I якщо типологічні, будівельні й технологічні досягнення у будівництві можна спробувати пояснити “одномоментним” результатом діяльності запрошених майстрів, неможливо пояснити з цієї позиції стрімке входження Русі вже в ХІ ст. до кола найрозвиненіших європейських держав, з якими Русь стала “на рівних", демонструючи таку духовну зрілість, яка не приходить за кілька десятиліть технічного розвитку. Існували певні чинники, завдяки яким Русь виявилася підготовленою не лише до запозичення християнської художньої культури, але до їі творчого переосмислення, трансляції духовного теоцентричного змісту через небачені до тих часів складнопірамідальні архітектурні композиції, відсутні у країнах візантійського кола. Вплив цих чинників, - як автохтонних, так і зовнішніх, - на формування будівельної культури Русі досі залишається поза увагою науковців.

За відсутності досліджень генези культури Русі-України розвиток останньої розглядають мало не “з чистого аркуша", традиційно виводячи з потужного імпульсу культури Візантії, що, однак, досі не вдалося зробити переконливо (О. Пламеницька, Є. Пламеницька 1-2). І тому історики архітектури, урбаністики й мистецтва переглядають відомі дати й дані (Никитенко; Климовский 313), шукають глибинні витоки архітектури Київської держави в дохристиянській автохтонній традиції дерев'яного будівництва (Логвин 110-111), а зародження містобудівної культури пов'язують з урбаністичним досвідом першого тисячоліття нашої ери (Ерофалов).

Актуальність дослідження. Особливої уваги заслуговує розвиток інженерно-будівельного мистецтва на південно-руських землях, зокрема на Середньому Подністер'ї, яке на початку I тис. н. е. було частиною Європейської Сарматії, пізніше - Барбарикуму, а згодом - Галицько-Волинської Русі. Ці землі, через їхній порубіжний, буферний характер, тісніше за інші контактували з провінціями Римської імпеpiï, зокрема з романізованою Дакією (О. Пламеницька, $Є$. Пламеницька 57-58). Втім, їхню геополітичну роль у ранній історії Русі досі не з'ясовано. В епіцентрі цієї території розташо- ваний Кам'янець-Подільський, деякі споруди якого акумулюють настільки важливу інформацію, що спонукають до перегляду історії усього регіону. До таких споруд належить Замковий міст - найзагадковіший і найменше досліджений об'єкт міста, невідомий широкому науковому загалу й маловивчений фахівцями.

Зв'язок роботи 3 важливими науковими та практичними завданнями. Замковий міст є пам'яткою архітектури національного значення Національного історико-архітектурного заповідника “Кам'янець” (iл. 1). Задокументована у 1950-х рр. аварійність мосту, спричинена значними експлуатаційними навантаженнями, на початку 1980-х стала приводом грунтовного вивчення споруди й опрацювання у 2000 р. проекту його реставрації*, який досі не реалізовано. Публікація результатів досліджень пам'ятки має на меті вироблення стратегії іiі збереження.

Аналіз останніх досліджень та публікацій. До 1985 р. Замковому мосту не було присвячено жодної публікації. Вперше на пам'ятку звернула увагу автор цих рядків, яка висловила думку про появу віадука в перші століття нашої ери як комунікації розміщеного на острові військового поселення римлян, заселеного перед тим даками. Матеріали на підтвердження такої атрибуції публікувалися в науковій літературі як частина гіпотези дако-римського походження Кам'янцяПодільського (О. Пламеницкая, Особенности; O. Plamenytska, E. Plamenytska, Daco-Roman; Є. Пламеницька, О. Пламеницька, Нова концепція; Є. Пламеницька, О. Пламеницька, Фортечний; О. Пламеницька, Є. Пламеницька, Кам'янець-Подільський). Дослідники мосту, які вивчають його матеріальну структуру, послідовно трансформують гіпотезу в концепцію, пред’являючи солідну доказову базу (О. Пламеницкая, Исследования; О. Пламеницька, До питання; O. Płamienicka, J. Rymsza, Kamyanets Podilsky; O. Plamenytska, E. Plamenytska, Most Zamkowy; O. Plamenytska, Recenti; О. Пламеницька, До пи-

\footnotetext{
* Проект реставрації Замкового мосту виконав українсько-польський колектив у співпраці Фонду «Замковий міст» (президент О. А. Пламеницька) з польською Фундацією «Most» (президент доктор-інженер Януш Римша) та Варшавським науково-дослідним інститутом доріг і мостів (директор Лєшек Рафальський) за фінансової підтримки Прем’єр-Міністра Польщі Єжи Бузека та Канцелярії Прем’єр-Міністра Республіки Польща (координатор доктор Войчех Чайка).
} 


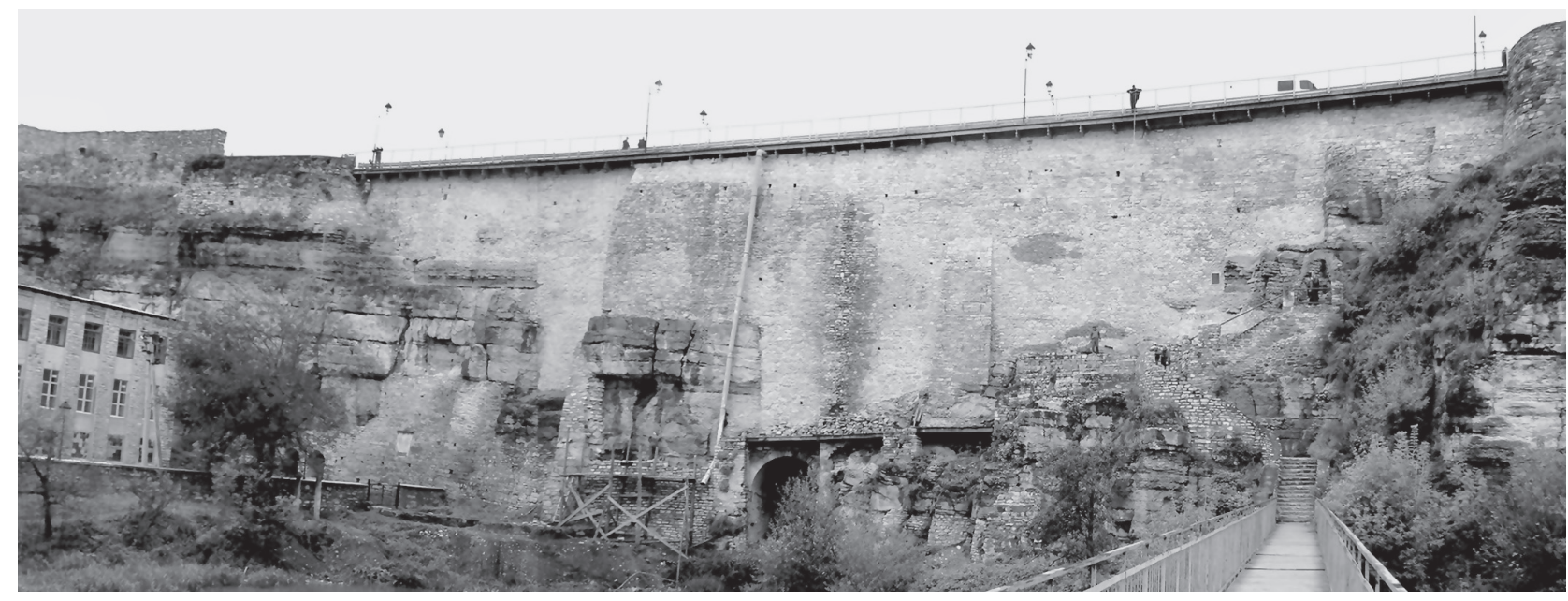

Iл. 1. Замковий міст у Кам’янці-Подільському. Сучасний стан. Фото автора

тання; О. Пламеницька, Княжа доба; О. Пламеницкая, Крепость). Ї̈̈ найгрунтовніший виклад містять монографічні праці автора (О. Пламеницька, Є. Пламеницька, Кам'янеиь-Подільський 38-52; О. Пламеницька, Castrum 130-143; О. Пламеницкая, Casus pontis).

Суть концепції полягає в наступному. За часів Траянових воєн 101-107 рр. Дакія (сучасна Румунія) була перетворена на римську провінцію. Прилегла до неї з півночі територія Європейської Сарматії контролювалася римськими військовими з'єднаннями. До початку Траянових війн частина даків мешкала у верхів'ях Дністра, відтак ця територія та лівобережжя Дністра нижче за течією потрапили під контроль Риму. Наявність на Поділлі поселень, назви яких мають дакійське закінчення “дава” (“укріплене місто”), численні знахідки римських монет та монетних скарбів, а також римських військових дипломів* (О. В. Надвірняк, О. Погорілець, О. О. Надвірняк, Римські) і речей римського військового побуту (Левада), залишки Траянових валів (Кучера) у поєднанні з повідомленнями Птолемея про міста даків на лівобережжі Дністра (Ptolemeai 420-21) і свідченнями істориків XVII ст. про приналежність частини Європейської Сарматії дакам і перебування на ній рим-

\footnotetext{
* Римські військові дипломи надавалися при виході у відставку ветеранам військових підрозділів, які в період служби не мали римського громадянства, а також ветеранам преторіанської гвардії, міських когорт і гвардійської кавалерії, які були громадянами Риму, гарантуючи їм додаткові права, зокрема право на одруження з місцевими жінками та на римське громадянство їхніх дітей.
}

ських легіонів (Liske 177-8), формують історичний контекст концепції, в якому Замковий міст розглядається у колі фортифікаційних споруд Кам'янця-Подільського II ст. н. е. Характер контактів цієї території з Римською імперією (iї заселення або військова присутність та контроль) $\epsilon$ предметом подальших досліджень.

Вивчаючи пов'язані з пізньоантичною епохою пам'ятки Поділля, дослідники доповнюють доказову базу концепції в контексті макроісторичних процесів у Центрально-Східній Європі (О. В. Надвірняк, О. Погорілець, Штрихи; Данілов; Okoń; Ерофалов). Деякі історики заперечують концепцію, вимагаючи на іiї підтвердження масових археологічних знахідок та писемних джерел. Втім, ми повинні розуміти, що писемних джерел, синхронних існуванню дако-римського Кам'янця, ми не знайдемо, очевидно, ніколи. Римська військова присутність у регіоні тривала декілька десятиліть, відтак імовірність виявлення масових артефактів у перекопаних культурних шарах Старого міста у рази знижується. Водночас, випадково виявлені у Кам'янці-Подільському речі римського періоду свідомо замовчуються. Так, масова знахідка при земляних роботах у Старому місті у 2012 р. залізних наконечників римських списів - пілумів не була зафіксована місцевими археологами і стала здобутком “чорної археології” *. Більше

\footnotetext{
* За інформацією архітектора I. Оконченка, у 2012 р. він оглядав у Львові виявлені в Кам'янці-Подільському знахідки римських пілумів: одиничну та масову (кілька пілумів, загорнутих в автентичну тканину). Зафіксувати знахідки не вдалося. Їхня подальша доля
} 
пощастило понад 30 знайденим на Поділлі й Волині римським військовим дипломам, які були введені до наукового обігу і стали вагомим свідченням перебування на території Поділля римських військових з'єднань (О. В. Надвірняк, О. Погорілець, О. О. Надвірняк, Римські).

Зазначення невирішених раніше частин загальної проблеми, яким присвячується стаття. Одним з аспектів комплексних досліджень Замкового мосту є коло його типологічних і хронологічних аналогів, що можуть заповнити прогалину доказової бази хронотипологічної атрибуції мосту.

Новизна наукового дослідження. Проблема визначення історико-урбаністичного контексту появи Замкового мосту на землях Європейської Сарматії в епоху Траянових війн є новою в історіографії архітектури України. Новою є також спроба визначення кола аналогів мосту шляхом аналізу іконографії всесвітньовідомої пам'ятки монументального мистецтва - рельєфів Траянової колони в Римі.

Методологічне значення авторських розробок. Завдання роботи - визначити місце Замкового мосту в історії архітектури ЦентральноСхідної Європи. За відсутності в Україні подібних архітектурно-інженерних споруд дослідження має методологічне значення для розвитку історико-архітектурної науки.

Виклад основного матеріалу. Замковий міст розміщений на гребені скельного перешийку між островом і плато, сполучаючи Старе місто зі Старим замком (iл. 2). Оскільки упродовж століть міст був єдиною стаціонарною комунікацією міста на острові з плато, вік міста значною мірою визначається віком мосту.

Наукова інтрига у вивченні Замкового мосту полягає у принциповій різниці між його теперішнім виглядом (потужний суцільний кам'яний мур) та описами й іконографією кінця XVIXVII ст., що фіксують багатопрогінний кам'яний віадук у вигляді аркади на пілонах (iл. 3). Цю невідповідність пояснюють джерела, які повідомляють, що в 1685-1687 pр. міст, пошкоджений

невідома. В той період у Старому місті проводилися масштабні земляні роботи для будівництва поблизу Вірменського бастіону, в декількох десятках метрів від Замкового мосту. Пілуми, вірогідно, було виявлено саме там.
1672 р. під час облоги Кам'янця турками, було реконструйовано. Турецькі інженери засипали аркові прогони мосту, старі пошкоджені арки зміцнили новими, влаштованими вище, а міст обмурували з обох боків суцільними ескарповими мурами. Поспішно виконані роботи стали причиною руйнацій обмурування у XVIII та XIX ст. Під час ремонтів і реконструкцій мосту 1841,1855 , у 1870-х рр. та 1942 р. обмурування

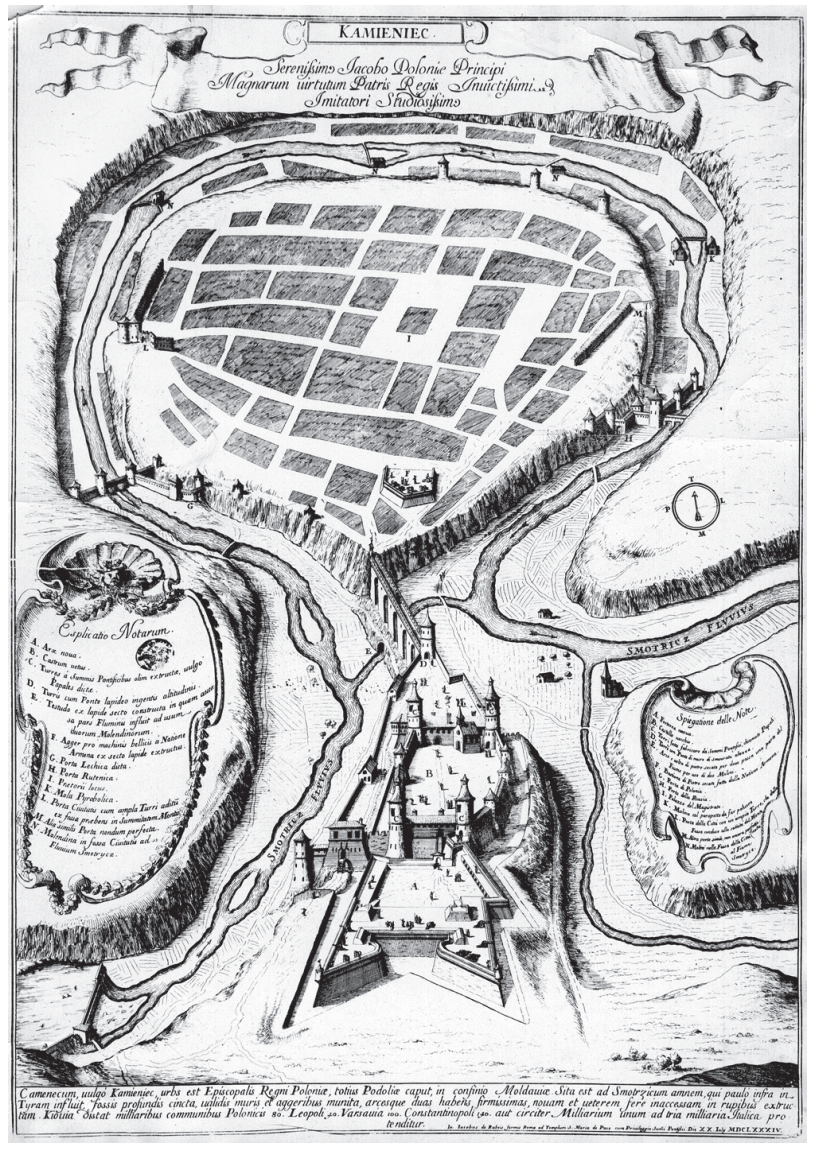

Іл. 2. Замковий міст у містобудівній ситуації Кам'янця-Подільського. Гравюра 1684 р.

(за: Пламеницька О. Castrum 281)

було відновлено, а мостові парапети й надбрамні башти розібрано (О. Пламеницька, Castrum 550-60). Таким чином, предмет дослідження аркова конструкція давнього мосту - виявилася частково втраченою, частково похованою під кам'яним “саркофагом”, утвореним ескарповими мурами.

Один з етапів натурного дослідження, присвячений арковій конструкції мосту, обстеженій через спеціально влаштовані отвори-колодязі у дорожньому полотні (з виконанням обмірів чотирьох прогонів та відбором 77 зразків мурувальних розчинів з різних частин пілонів, арок 

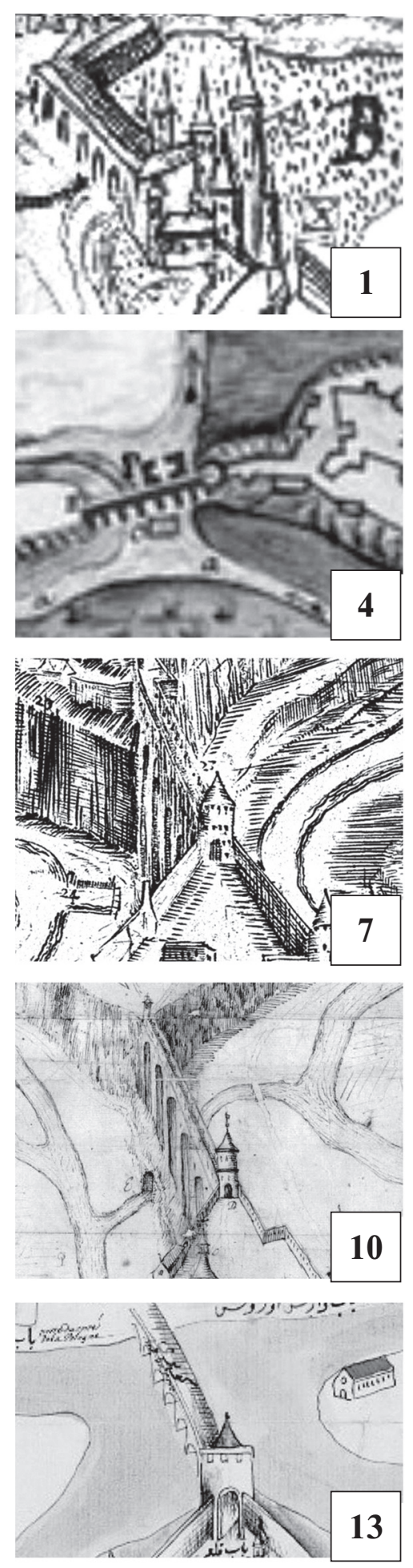

Iл. 3. Стан Замкового мосту, відображений на історичній іконографії: 1, 2- 1633 р.; $3-1651$ p.; 4-1650-1670 pp.; 5, 6- до 1672 p.; 7-15-1673-1687 pp.; 16- 1692 p.; $17-1699 \mathrm{p}$.

Опрацювала О.Пламеницька (за: Пламеницька O. Castrum; Opyrchał L. Drukowane plany ...)
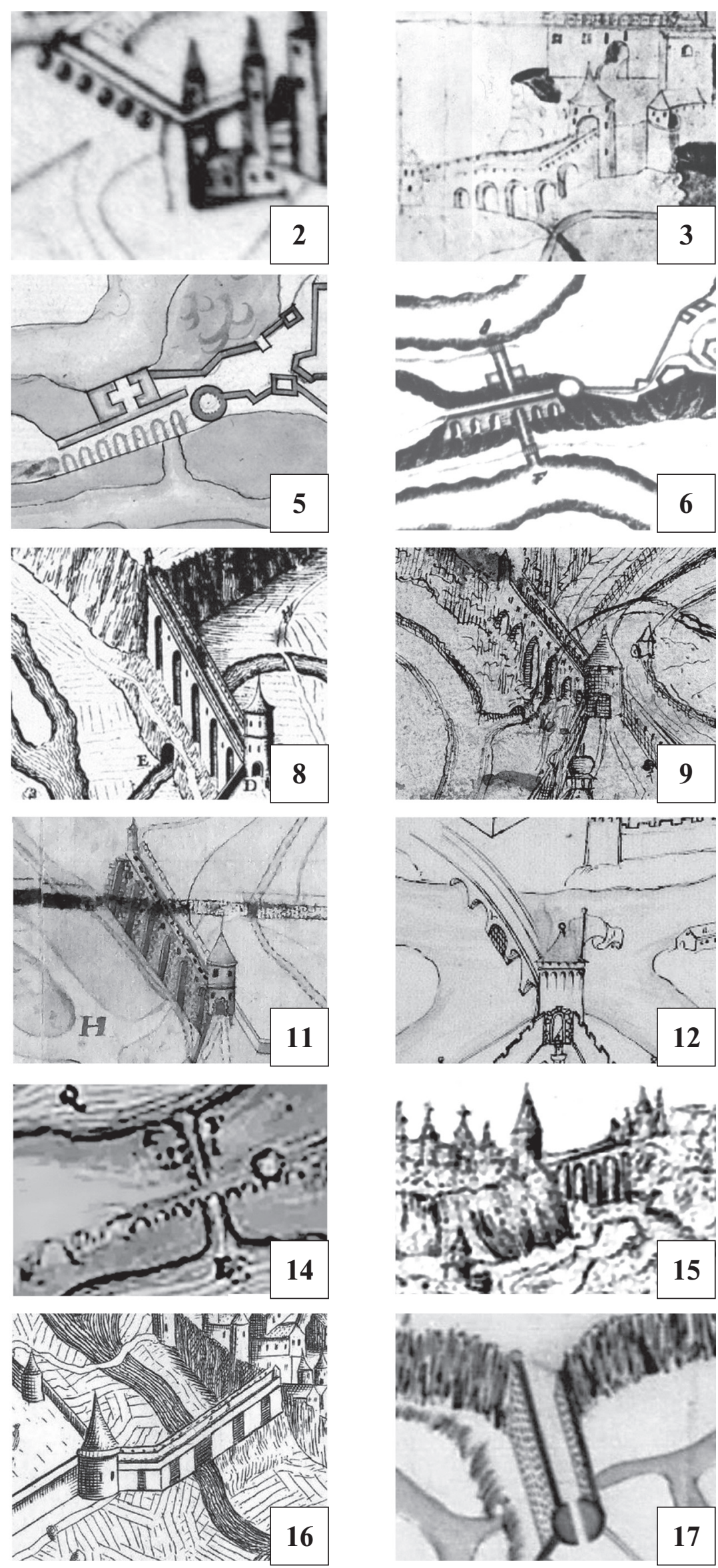

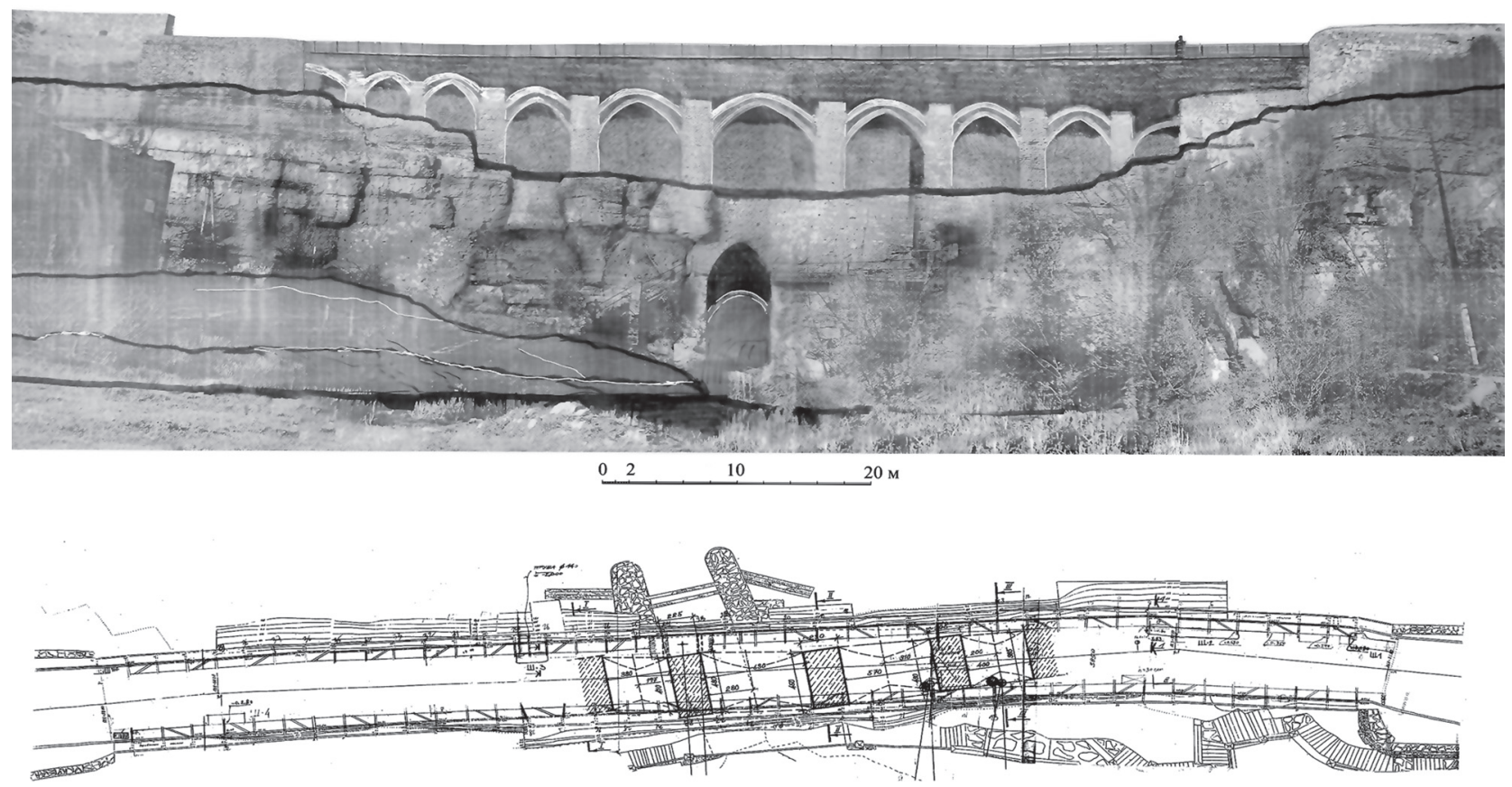

Іл. 4. Замковий міст у Кам'янці-Подільському.

Bгорi - внутрішня структура (поздовжній переріз; бічні арки - гіпотетично).

Реконструкція О. Пламеницької.

Внизу - фіксаційний план дослідженої частини прогонової споруди

(за матеріалами НДІТІАМ, Укрзахідпроектреставраціі)

та ескарпових мурів) підтвердив наявність під ескарповими мурами двох поясів арок. Виявилося, що нижні арки мають стрілчасту форму, а верхні - пологу. Пілони поставлено без фундаменту на гребінь перешийку, утворений скельними монолітами (iл. 4). Пристосовуючись до їхньої конфігурації, будівничі ставили пілони на зручних ділянках скелі, що зумовило ламану вісь мосту та різні розміри прогонів $(3,8 \mu+6,3 \mu+$ $+5,7 м+4,0$ м $)$ і пілонів $(2,25 \times 4,8 m ; 2,3 \times 4,5 м$; $2,05 \times 4,3$ м). За сукупними даними, міст мав п’ять повних прогонів.

Встановлена на основі натурних та іконографічних досліджень будівельна періодизація мосту нараховує десять етапів (О. Пламеницька, Castrum 130-43, 272-78, 427-31); основним 3 них притаманні характерні мурувальні розчини. Щодо елементів давнього мосту виділено дві групи розчинів: пілонів (I-A) та нижніх стрілчастих арок (I-B), що за даними хімікопетрографічного аналізу відрізняються складом і фізико-механічними властивостями. Розчини групи I-A не мають аналогів у середньовічних спорудах Кам'янця-Подільського, водночас ідентичні розчинам, на яких змуровані найдав- ніші вежі Старого замку, датовані II-III ст. н. е. за складом археологічного матеріалу, виявленого в супутніх археологічних шарах* (О. Пламеницька, Є. Пламеницька, Кам'янець-Подільський 23-38; О. Пламеницька, До питання; О. Пламеницька, Castrum; О. Пламеницкая, Крепость), а також мають властивості, аналогічні до розчинів римських укріплень Мезіï (Bernacka-Lubańska $161,169,171)$. Розчини групи B-I є характерними для будівництва періоду пізнього Середньовіччя і мають датований аналог - вірменську Благовіщенську церкву кінця XIII - початку XIV ст. (Antoni 109). У цей період у місті утворюється вірменська громада й розпочинається кам'яне будівництво. 3 огляду на притаманну вірменській будівельній техніці стрілчасту форму ниж-

\footnotetext{
* На думку хіміків-петрографів, «зміна технології виготовлення будівельних розчинів може бути пов'язана з історичними подіями, що призвели до заміни майстрів-будівничих фортеці представниками нової школи в будівельній справі» (Е. Нашиванко, Ю. Стріленко). Заключение лаборатории УСНРПУ по результатам анализа строительных растворов Каменец-Подольской крепости. 1971. - Архів інституту УкрНДІпроектреставрація (копія в особистому архіві автора).
} 
ніх арок їхнє спорудження можна пов'язувати 3 діяльністю вірмен.

Таким чином, отримано перший важливий для подальшого дослідження висновок: щодо післямонгольського періоду, коли було зведено муровані стрілчасті арки, попередній період, пов'язаний зі спорудженням мурованих пілонів, відрізняє принципово відмінна будівельна технологія, яка, на думку хіміків-петрографів, характеризує будівельну школу з високою культурою виготовлення в'яжучих матеріалів. Другий важливий висновок випливає з першого: оскільки ані за часів домонгольської Русі, ані у ранньослов'янський період не зводили мостів 3 кам'яними опорами, отже версія про місцеве походження будівничих кам'яного мосту виключається, а хронологія появи споруди опускається до початку нашої ери. Третій висновок стосується архітектури первісного мосту, що складався з мурованих пілонів та, ймовірно, дерев'яної прогонової споруди.

Ареал пошуку типологічних аналогів Замкового мосту визначився з огляду на заглиблення хронології мосту та на відсутність зв'язку з автохтонними будівельними традиціями. Враховуючи повідомлення джерел XVII ст. про Кам'янець як про місто, “збудоване даками” (Cellarius 349; Cyaneae) та інформацію дипломата XVII ст. Ульріха фон Вердума про перебування римських легіонів на лівобережжі Середнього Дністра в період Траянових війн (Liske 177-8), увагу було сфокусовано на об'єктах будівництва в ареалі давньої Дакії та прилеглої території.

Інформацію про такі об'єкти містить пам'ятка монументального мистецтва - колона Траяна в Римі, зведена у 113 р. н. е. на честь перемоги над Дакією. Фуст колони вкриває спіральний пояс рельєфів, що ілюструють події дакійської війни (iл. 5). “Каркас” цих подій створили Діон Кассій (Dio’s Roman History 155-235) та Амміан Марцеллін (Ammiani Marcellini 330-400), які не були сучасниками Траянових війн і користувалися опосередкованою інформацією. Насичення цього “каркасу” подробицями з хронологічними й географічними прив'язками є результатом праці численних дослідників, які використовували рельєфи колони Траяна. Історичну й географічну інтерпретацію більшості рельєфів дав Конрад Цихоріус у праці
1900 p. (Cichorius). Йдучи його слідами, дослідники трактували рельєфи мало не як графічний синопсис дакійської війни, прив'язуючи їх до місцевостей за більш ніж розпливчастими ознаками і наповнюючи “каркас" розповіді Діона Кассія деталями (Davies; Рубцов), запозиченими з інших джерел з історії Риму. Водночас, розважливий аналіз рельєфів колони Траяна неодмінно приводив дослідників до висновку, що за наявними скупими джерелами встановити перебіг, час та місце конкретних подій неможливо (Salmon 88). Автор “Історії Риму” Теодор Моммзен зазначав:

Імператор [Траян. - O. П.] сам написав історію цієї війни, подібно до того як Фрідріх Великий написав історію Семирічної війни і як багато хто робив це після нього; але ця праця до нас не дійшла. Нікому не спаде на думку відновлювати історію Семирічної війни на підставі картин Менцеля. Так і Траянова колона залишає в нас, крім деякого уявлення про окремі тьмяні епізоди, лише сумне відчуття великої і бурхливої історичної катастрофи, яка назавжди пішла в сутінки історії, не залишивши по собі навіть спогадів (Моммзен 196).

Сучасні вчені поступово доходять висновку, що рельєфи не відображають деталей війни в

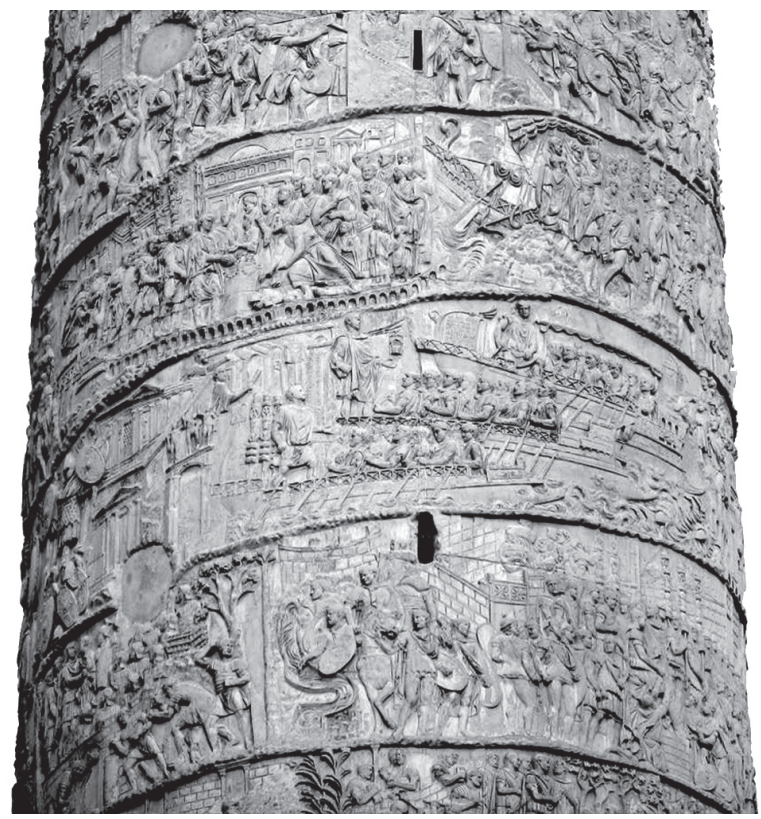

Іл. 5. Колона Траяна в Римі. Середня частина фуста. На другому згори ярусі рельєфів показано багатопрогінний арковий міст Аполлодора через Дунай (рельєф № LXXXVI); атрибуція О. Пламеницької. Фото А. Мокану 


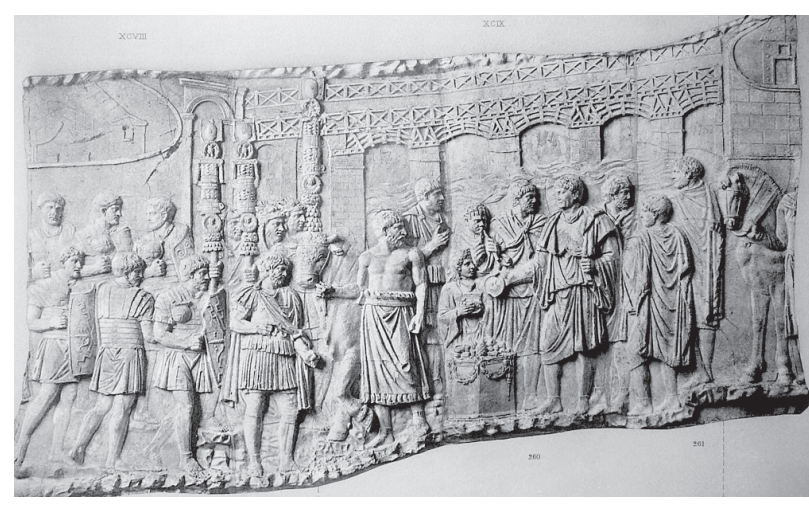

Іл. 6. Колона Траяна в Римі. Рельєф № XCIX, який помилково атрибутовано як міст

Аполлодора через Дунай (за: C. Cichorius)

хронології і що колона Траяна відігравала роль пропаганди досягнень Траяна (Nemeti).

Знайомлячись з рельєфами колони i, безумовно, не претендуючи на їхнє детальне вивчення, ми ставимо лише два предметні питання: чи можна визначити - що саме зображено на рельєфах і чи можна встановити - де знаходяться зображені об'єкти. 3 більшою чи меншою вірогідністю можна відповісти на перше питання, і з дуже значною долею припущення на друге. Адже встановити окремі локації військових сутичок та розташування кастеллумів, як і визначити траси гірських маршрутів легіонів Траяна можна лише гіпотетично. Значна части- на інтерпретацій подій війни, встановлених за рельєфами колони Траяна, базується на хиткій документальній основі й має безліч домислів. 3 точки зору загального контексту війни вони не принципові, але важливі з точки зору топографічної прив'язки рельєфів.

Одним з ключових епізодів початку другої дакійської війни був перехід римських легіонів через Дунай в районі дакійського міста Дробети, де було споруджено грандіозний стаціонарний міст. Рельєф № XCIX (iл. б) на колоні Траяна одностайно атрибутовано дослідниками як зображення цього мосту (Cichorius 135-41; Gazzola 136-7). Його конструктивне вирішення (дерев'яні аркові ферми на кам'яних пілонах), а також відношення до епохи Траянових війн привернуло нашу увагу як аналог конструкції першого будівельного етапу Замкового мосту.

Міст через Дунай зберігся у вигляді підводних залишків мурованих пілонів та фрагментів берегових опор у румунському місті ДробетаТурну-Северин та у сербському місті Кладово (iл. 7). На основі обмірів 1858 р., розкопок берегової частини мосту 1979 р. та підводних фотометричних обмірів залишків пілонів, проведених 2003 р., довжина мосту визначається як 1158,33 м, ширина прогону в осях $-51,4-57,0$ м
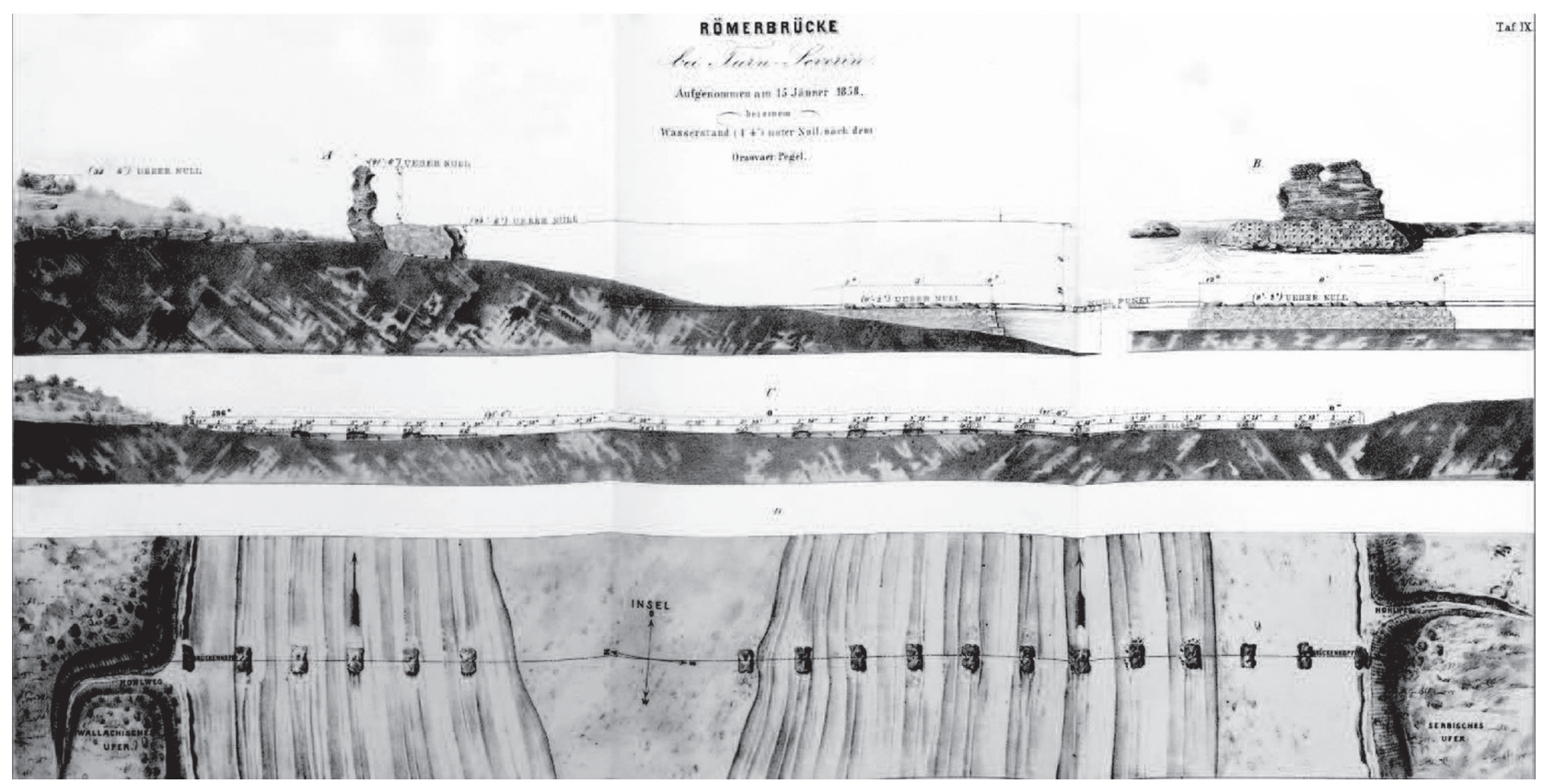

Іл. 7. Залишки мосту через Дунай. Обміри 1858 року.

Bгорi - берегові опори; посередині - опори річкової частини; внизу - план мосту (місто Дробета - ліворуч) (за: Găzdac C., Alföldy-Găzdac Á. 63) 
(середня 54,0 м) (Tudor, Podurile romane 113; Karović, Mihajlović, Vučković 285).

За повідомленням Діона Кассія будівничим мосту був Аполлодор Дамаський - сирієць грецького походження, офіційний архітектор імператора Траяна й учасник дакійських війн. Міст було зведено перед початком другої дакійської війни, 103-105 р. н. е. Діон Кассій залишив єдиний в історії опис мосту, з якого дізнаємося, що міст був “кам'яний” і мав 20 опор, зроблених з квадрів; висота опор становила 150 футів* $(44,4$ м), ширина - 60 футів $(17,8$ м), розмір прогону -170 футів $(50,3 \text { м })^{* *}$. Опори з'єднувалися арками, матеріал яких не вказано (Dio's Roman History 13). Чи бачив історик міст на власні очі через століття після будівництва, чи описав споруду за чужими розповідями, невідомо. На користь першого припущення говорить його захоплення мостом, який “перевершив усі чудові творіння Аполлодора”. Діон Кассій також повідомляє, що наступник Траяна Адріан розібрав верхню частину мосту

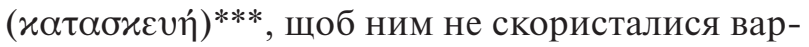
вари (Dio's Roman History 13).

Дотепер опис Діона Кассія залишається єдиним автентичним джерелом, адресно прив'язаним до мосту Аполлодора. Другим джерелом міг бути написаний Аполлодором трактат про спорудження мосту (Gazzola 136-7), але, на жаль, твір не зберігся. Третім автентичним джерелом міг стати щоденник імператора Траяна про дакійські війни, але він також не дійшов до нас (Моммзен 196).

Скупість прямої джерельної інформації стосовно мосту через Дунай змусила дослідників використовувати непрямі джерела. Виходячи з припущення, що міст як важливий елемент дакійської війни конче мав бути відтворений на колоні Траяна, вони прийняли за умовчанням, що зображений на рельєфі № XCIX міст 3 мурованими опорами і дерев'яними арковими фермами (див. іл. 6) є мостом Аполлодора. Відтак per tacitum consensum зображення на колоні Траяна стало єдиним джерелом інформації про архітектуру мосту через Дунай. Сумніви деяких дослідників щодо такої атрибуції зображення не

\footnotetext{
* Римський фут дорівнював 0,296 м.

** Розмір зазначено в осях.

*** Дослівний переклад з грецької - «споруда».
}

були підтримані науковим загалом. Втім, вони варті уваги.

Зокрема, Е. Сальмон звертає увагу на те, що опис Діона Кассія не зовсім зрозумілий 3 огляду на те, що не вказано матеріал арок. На його думку, “кам'яні арки з прогоном у 170 футів є серйозною архітектурною проблемою”; водночас він вважає, що “за часів Адріана, якщо вірити Діону Кассію, верхню частину мосту було знесено і, правдоподібно, порівняно легко". Він також вважає, що для більшості дослідників такі міркування як аргумент дерев'яних арок є переконливими, отже, відповідно до їхніх висновків, верхня частина мосту була дерев'яною (крім берегових прогонів). Водночас Е. Сальмон обгрунтовує сумніви відносно дерев'яних арок:

... підставу для роздумів з цього приводу дали результати розкопок 1931 р. на румунському березі Дунаю, на початку мосту, під час яких було знайдено грубо оброблений мармуровий медальйон, на аверсі якого зображено кінну фігуру Траяна, а на реверсі - міст, що природно атрибутується як міст Аполлодора. У мості, зображеному на медальйоні, верхню частину складено, поза сумнівом, з кам'яних блоків. Відтак питання з верхньою частиною мосту Аполлодора можна вважати закритим, хоча деякі пояснення щодо медальйону ще має бути знайдено. (Salmon 97-8)

Знахідка медальйона є серйозним артефактом. Можливо саме через це про нього не згадують у контексті досліджень мосту: зображення на ньому іде врозріз з десятками публікацій.

Втім, саме аспект будівельного матеріалу арок мосту $є$ найважливішим. Нашу увагу привернули деталі, що свідчать про разючу відмінність конструкції мосту, зображеної на колоні Траяна і просторової структури реального мосту через Дунай. Першою відмінністю є розбіжність між двадцятипрогінним дунайським мостом 1158 м завдовжки та п'ятипрогінним мостом на рельєфі колони Траяна. Ступінь деталізації зображення, на якому виразно зафіксовано дрібні конструктивні елементи та навіть цвяхи в місцях їхнього з'єднання, свідчить, що міст на рельєфі є невеликою спорудою. Визначити іiі довжину* неважко, однак викликає подив,

* Можемо говорити про загальну довжину, оскільки на рельєфі виразно показано обидва береги. 
що ніхто з дослідників цього не зробив. I хоча рельєф на колоні є не масштабованим креслеником, а художнім зображенням, він відображає пропорції та конструктивну схему мосту, які не дають підстав для його ототожнення з мостом через Дунай. Тож не дивно, що всі дослідники, які стверджували, що на колоні Траяна зображено дунайський міст, не констатували подібність прототипу й зображення, а пояснювали відмінності між ними.

Не можна скидати з рахунку, що архітектор та інженер, учасник експедиції Траяна й автор проекту мосту через Дунай Аполлодор Дамаський брав участь у спорудженні колони Траяна (Stephenson 83-4). К. Цихоріус небезпідставно приписує Аполлодору не лише архітектурну частину проекту, але й участь у створенні рельєфів. Їхня деталізація щодо споруд, конструкцій, зброї, одягу римлян і даків, портретне розмаїття людей (частина з яких, можливо, має реальні прототипи) свідчить, що ескізи рельєфів виконував не лише художник, але архітектор та інженер i, що найголовніше - очевидець подій. Не випадково колоні присвячено десятки наукових праць, які розглядають iĭ як джерело вивчення військової та будівельної справи, верифікуючи зображення даними археологічних досліджень (Šimić-Kanaet).

Якщо рельєфи виготовлялися під наглядом Аполлодора, або ж, імовірно, за його ескізами, виникає питання - наскільки приблизно чи умовно архітектор показав розроблену ним самим унікальну інженерну конструкцію мосту, який за свідченням Діона Кассія, не мав аналогів? Логічно припустити, що Аполлодор, який відтворив на колоні вигляд дакійських фортець, римських фортів і невеличких дерев'яних мостів, мав у той чи інший спосіб увічнити власне інженерне творіння. I він навряд чи подав би зображення збудованого ним мосту з такими разючими відмінностями. Адже на колоні зображено звичайний міст, у конструкції якого немає нічого революційного.

Масштабним елементом будь-якого мосту є висота перил, сумірна до людського зросту. За часів Аполлодора Дамаського мірним модулем була грецька римська стопа $(0,296$ м), тож правдоподібно, що висота перил могла становити 4 або 5 стіп (відповідно 1,19 та 1,49 м). У збереже- них римських мостах висота перил максимально сягає плечей пересічної людини. Тож розглянемо варіанти з різною висотою перил, приймаючи за модуль 1,19 м та 1,49 $м$. За співвідношенням висоти зображених на колоні перил та ширини прогону $(1: 3,5$ або $1: 4)$, прогін становить відповідно 4,17 $(5,18)$ та 4,76 $(5,92)$ м. Ширина пілонів по фасаду дорівнює 1,8 модулі - 2,15 $(2,69)$ м. Розмір мостових прогонів на рельєфі коливається в межах 4,0-6,0 метрів. Відповідно, довжина мосту між двома берегами становить 28 модулів або 33,6 $(41,44)$ м. Пілони мосту зображено складеними з кам'яних блоків, яких по ширині фасаду пілону укладено 2,5 . Отже, розміри блоків становлять $0,56(0,68) \times 0,28(0,34)$ м.

Таким чином, на колоні Траяна зображено невеличкий п'ятипрогінний міст завдовжки близько 40 м 3 прогонами в межах 4,0-6,0 м, перекритий дерев'яними арковими фермами, кожна $з$ яких складається з чотирьох брусів довжиною $1,2(1,7)$ м. Така конструкція $є$ інженерно й архітектурно несуперечливою. Застосування для перекриття прогонів дерев'яних аркових ферм замість балок (їхя довжина мала б становити 4,5-7,0 м) можна пояснити бажанням уникнути пошуку довгих колод значного діаметру і наявність під рукою невеличких брусів, технологія з'єднання яких була напрацьована римськими будівничими. Доречно пригадати листи Плінія Молодшого, де він, описуючи дакійські війни, згадував про досвід “перекидання через річки нових мостів” (Письма Плиния 4). Конструкція верхнього поясу дерев'яної ферми (поверх якого лежав хідник), що працювала на стискання, мала очевидні переваги проти дерев’яної балки, що під вагою працювала на розтягнення та прогин.

Припустимо, що на колоні зображено міст через Дунай. За метричний модуль беремо встановлену натурними обмірами ширину прогону між пілонами - 40,5 м (у світлі). В такому випадку, виходячи з пропорцій зображення, висота перил мосту матиме абсурдний розмір - близько 12 м. Не менш абсурдними будуть розміри кам'яних блоків, з яких змуровані пілони $4,06(4,64) \times 2,03(2,32)$ м. При цьому загальна довжина мосту разом з береговими арками становитиме лише 405 м. Отже, зображення мосту на рельєфі № XCIX не можна атрибутувати як 
міст через Дунай через невідповідність ані загальної довжини, ані пропорцій, ані розмірів.

Не менші суперечності виявляє спроба перенести на дунайський міст конструкцію дерев'яних аркових ферм, зображену на рельєфі колони Траяна; з конструктивної точки зору вона виглядає ще абсурднішою. Застосування для перекриття прогону дунайського мосту в 40,5 $\mathrm{m}$ (у “світлі”) аркової ферми з чотирьох брусів означає, що довжина одного бруса становитиме близько 11 м. При такій довжині його перетин має бути не меншим від 0,4 м. Вага одного бруса* таких габаритів, залежно від породи дерева (дуб, бук, сосна), становить від 1,2 до 1,5 m. $€$ очевидним, що монтаж і встановлення навіть одного поясу ферми з чотирьох брусів загальною вагою 4,8-6,0 $m$ (що під час монтажу не матиме жорсткості) є нереальним. На зображенні з колони кожен прогін перекрито трьома такими поясами аркових ферм, змонтованими за концентричним принципом, відтак орієнтовна кількість одинадцятиметрових брусів для спорудження 20 арок мосту (за умови, що в кожному прогоні встановлено по три ферми по ширині мосту) сягне 720, не рахуючи елементів конструкції над пілонами, перил і хідників.

Конструктивна ідеологія зображеного на колоні Траяна невеличкого мосту, перенесена на грандіозний міст через Дунай, втрачає логіку. Її інженерна алогічність у випадку прив'язки до габаритів мосту через Дунай спонукала вчених, які виконували його графічні реконструкції, збільшувати кількість брусів ферм до 8-ми (Шуазі) та 11-ти (Дюпре) (Шуази 462; Tudor, Drobeta 27) (iл. 8). 3 цієї ж причини польський інженермостобудівельник Януш Римша, який разом 3 нами займався дослідженням конструктивних особливостей Дунайського мосту, дійшов несподіваного висновку:

Міст біля Дробети на Дунаї ніколи не був збудований попри те, що був запроектований Аполлодором, а будівництво було розпочато. Рештки опор мосту свідчать про спробу будівництва мосту. (Rymsza 37)

Італійський дослідник П. Гаццола також висловив аналогічну думку: міст було зображено

\footnotetext{
* Вологість деревини при визначенні удільної ваги приймаємо $80 \%$, оскільки легіонери на марші використовували свіжозрубаний ліс.
}

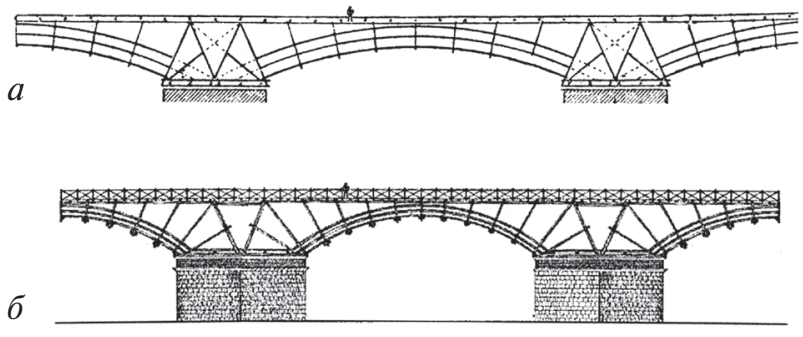

Іл. 8. Реконструкція аркових ферм прогонової споруди: $a$ - за О. Шуазі; $\sigma$ - за Е. Дюпре (за: Пламеницька О. Castrum 139)

на колоні раніше, ніж збудовано (Gazzola 13)! Але цей висновок не узгоджується з датою будівництва мосту (103-105 рр.) та датою зведення колони Траяна (113 р.).

Отже, цілковитий незбіг параметрів мосту на рельєфі Траянової колони та мосту Аполлодора через Дунай приводить до закономірних питань: чи дерев'яні арки дунайського мосту бачив Діон Кассій; чи дунайський міст зображено на рельєфі № XCIX?

За нашим переконанням, спорудження у складних гідрологічних умовах 20 мурованих пілонів 17,8 × 17,8 м з обличкуванням їх великими кам'яними блоками вагою 750 кг (знайдені в натурі) суперечить влаштуванню на пілонах недовговічної і трудомісткої дерев'яної конструкції, до того ж уразливої від пожеж. Також вважаємо, що досвідчений архітектор та інженер Аполлодор Дамаський не міг поставити у військових умовах такий експеримент. Водночас, не можемо погодитися і з Я. Римшею, який заперечує сам факт спорудження мосту через Дунай тільки через нераціональність зображеної на колоні Траяна конструкції. Адже достеменно не доведено, що на колоні показано саме дунайський міст.

Цілком очевидно, що загальновизнана атрибуція мосту на рельєфі № XCIX не має переконливого обгрунтування. Сдиним їі аргументом залишається те, що зображена споруда є мостом. Не знаходячи на колоні інших зображень, які б однозначно сприймалися як міст, дослідники переконані, що дунайський міст мав конче бути відтворений на колоні, з великими натяжками “прив'язали” до нього міст на рельєфі № XCIX. Звідси походить наступна помилка: брак джерельної інформації щодо вигляду мосту через Дунай поповнили з зображення на колоні. Але 
на колоні зображено невеличкий міст простої інженерної конструкції, який, як було доведено вище, за жодним параметром не відповідає мосту через Дунай. Коло замкнулося. Тоді який же міст бачив римський історик Діон Кассій?

Висновки. Античні історики не помилялись, описуючи міст через Дунай як кам'яний; це підтверджує й зображення на знайденому при розкопках у Дробеті кам'яному медальйоні. Діон Кассій невипадково назвав “руйнацією” спосіб знищення мосту Адріаном; дерев’яну конструкцію простіше було спалити. На нашу думку, свідчення про кам'яний міст, “який перевершив усі творіння Аполлодора”, слід пов'язувати з грандіозним бетонним арковим мостом з прогоном у 40,5 м (у “світлі” між пілонами), яким Аполлодор вперше довів можливості застосування римського бетону на великопрогінних конструкціях. Саме цим уславив себе геніальний сирієць з Дамаска, якому приписують зведення у 124 р. куполу римського Пантеону з прогоном у 43,3 м, виконаного з неармованого бетону, де як наповнювач було застосовано легкий пористий матеріал - туф. Додамо, що вчені досі не дали вичерпних відповідей на питання, пов'язані з конструкцією та технологією зведення купола Пантеону. Тому щодо конструкції зруйнованого дунайського мосту можемо висловити лише припущення.
На користь мурованих (бетонних) арок свідчить ширина опор мосту в поздовжньому напрямку $-17,8$ м. За правилами конструювання аркових мостів ширина опор, необхідна для погашення розпору арок, має становити третину ширини прогону. За цим параметром співвідношення ширини опор та прогону дунайського мосту $(54,0: 17,8=3,04)$ є класичним для мурованих мостів. Для спорудження бетонних арок мосту потрібна була опалубка, яку можна було робити з підручних дрібнорозмірних елементів деревини. Нарешті, руйнація аркової частини мосту теж свідчить на користь бетонної конструкції, оскільки пластичні властивості бетону поступаються муруванню на розчині. До того ж міст знаходиться на території Румунії, на межі сейсмічної зони Вранча.

Заперечуючи загальновизнану атрибуцію зображення на рельєфі № ХСІХ, ми стверджуємо, однак, що на колоні Траяна присутнє інше зображення, яке більше відповідає мосту через Дунай. На початку серії рельєфів, що відображають другу дакійську війну, яка, як відомо, розпочалася з переходу легіонів через Дунай, є зображення багатопрогінної аркади на пілонах (рельєф № LXXXVI), підніжжя якої омивають хвилі, а по верху рухаються люди (iл. 9). Інтерпретація цього зображення як “набережної портового міста”, зокрема Салони

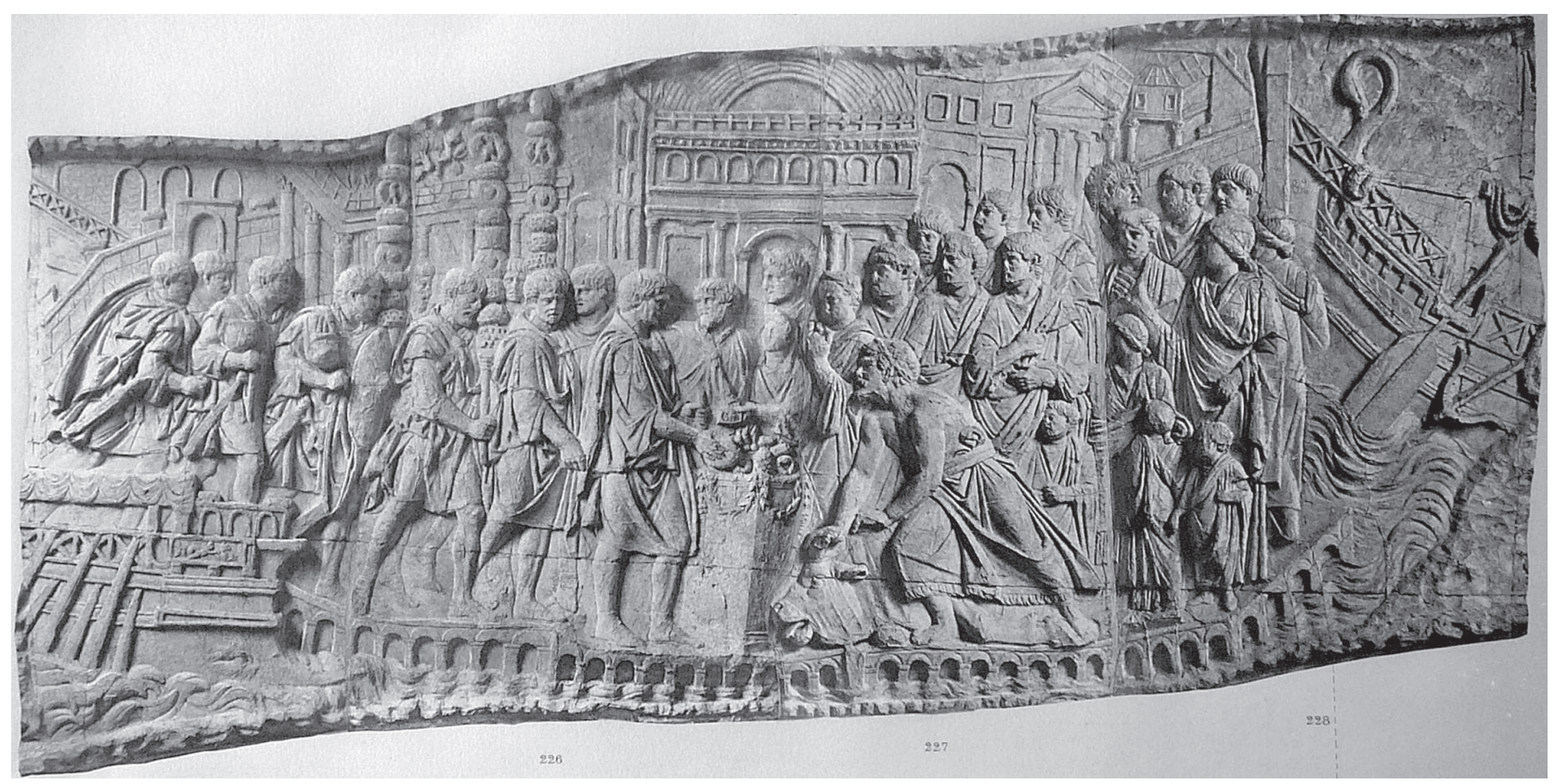

Iл. 9. Колона Траяна в Римі. Рельєф № LXXXVI з зображенням мосту Аполлодора через Дунай (атрибуція О. Пламеницької) (за: С. Cichorius) 

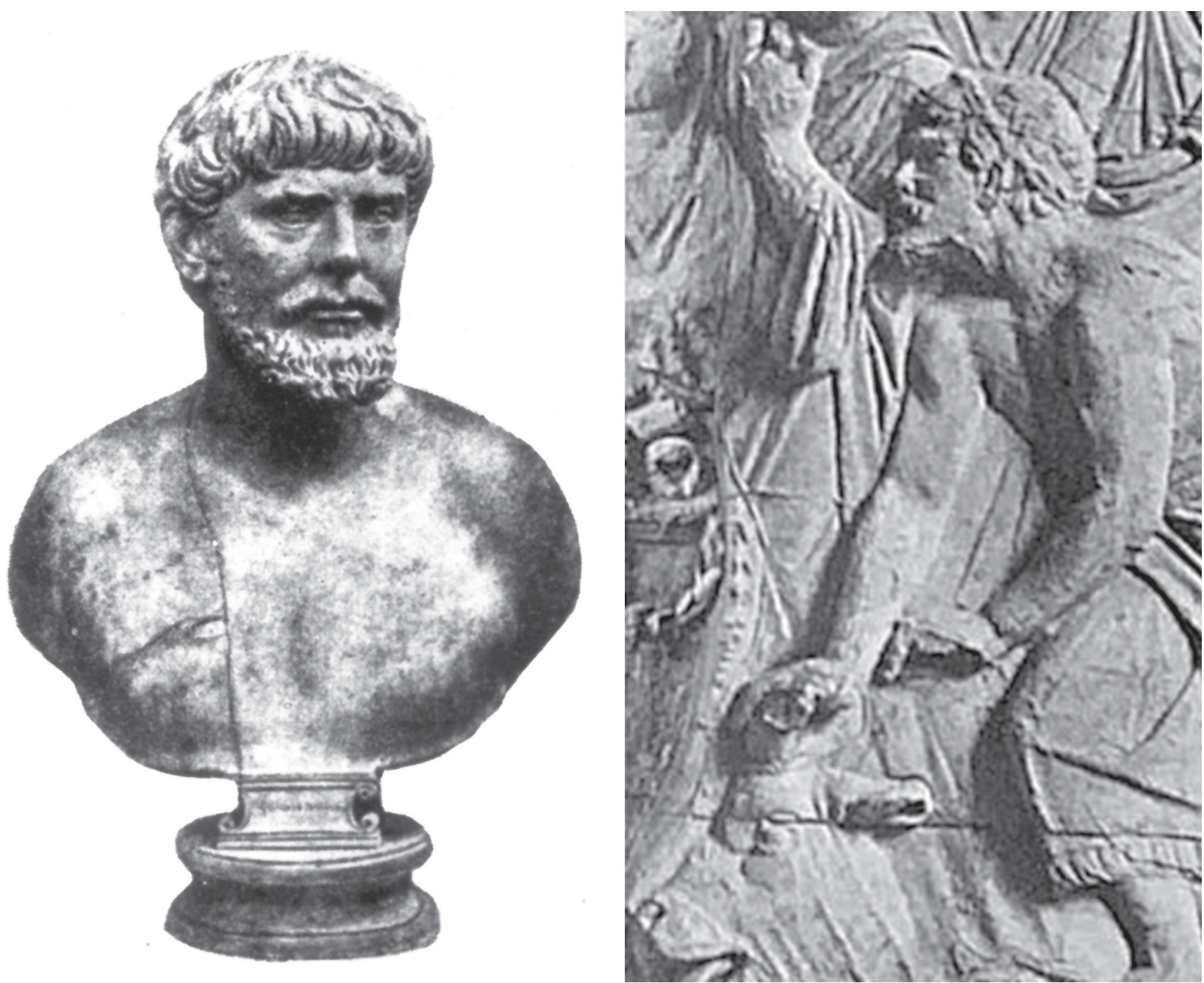

Іл. 10. Аполлодор Дамаський.

Ліворуи - бюст з Гліптотеки в Мюнхені. Праворуи - гаданий портрет на рельєфі № LXXXVI (атрибуція О. Пламеницької)

(за К. Цихоріусом), на наш погляд, є непереконливою. Набережна Салони (теперішній Спліт у Хорватії) не має залишків жодних подібних споруд, крім того, іiі топографічні характеристики не відповідають зображенню з високим берегом. До того ж набережна у вигляді аркади позбавлена конструктивного сенсу.

Ми переконані, що на рельєфі № LXXXVI зображено багатопрогінний мурований (бетонний) арковий міст. У центрі композиції, як і на рельєфі № XСIX, - ритуал офірування бика, який є ідентичним сцені № XCIX, що інтерпретується як офірування бика на честь інавгурації Траяном мосту через Дунай (Cichorius 135). Що стосується кількості арок (34) мосту, ліву частину якого затуляє корабель, то можна пояснити ії̈ як подвоєну $(20 \times 2=40)$ внаслідок “розгорнутого” зображення мосту - 3 торця, від протилежного берега. При такому зображенні панорама міста (можливо, Дробети) з амфітеатром та громадськими будівлями опиняється на другому плані, за мостом. План Дробети підтверджує цю версію.

Не можна не відзначити також значну портретну подібність жерця, який сильним рухом прихилив до землі голову бика, зі скульптурним портретом Аполлодора Дамаського, що зберігається в мюнхенській Гліптотеці (iл. 10) (Tudor, Podurile 65). Можливо, цей рух символізує підкорення Дунаю геніальним інженером і $є$ однією з численних алегорій рельєфів Траянової колони, і в такому випадку є цілком доречним.

Розглядаючи нову версію атрибуції зображення мосту через Дунай на колоні Траяна, що враховує обставини, які досі не знайшли пояснення, пропонуємо також нову версію атрибу- 


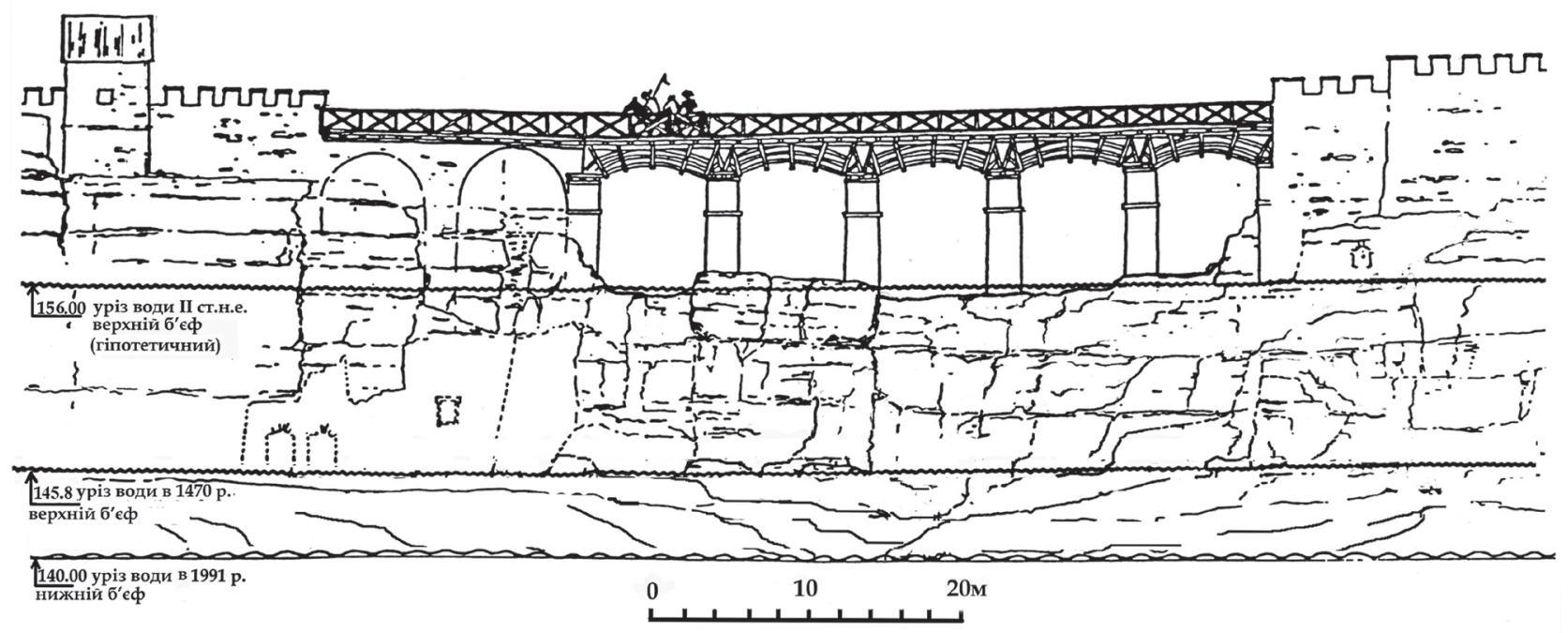

Іл. 11. Замковий міст у Кам'янці-Подільському.

Вигляд на поч. II ст. н. е. відповідно до аналога, зображеного на рельєфі № XCIX на колоні Траяна в Римі. Реконструкція О. Пламеницької та $Є$. Пламеницької

ції мосту на рельєфі № XCIX, який на колоні розташований вище, а в умовній хронології колони Траяна - “пізніше", тобто північніше Дробети. Оскільки римляни зводили численні мости через річки провінції, рельєф № XСIX може відображати один з типових військових мостів, розташованих на віддалених північних територіях, які потрапили під контроль римлян.
I тоді знаходять пояснення численні сцени, розміщені “між двома мостами”: вони означають просування легіонів Траяна з боями вглиб Дакії. Як далеко сягнули межі підконтрольної Римові території - питання історичної, археологічної та історико-архітектурної науки.

Враховуючи археологічні артефакти, якими рясніє земля Поділля, а також залишки форти-

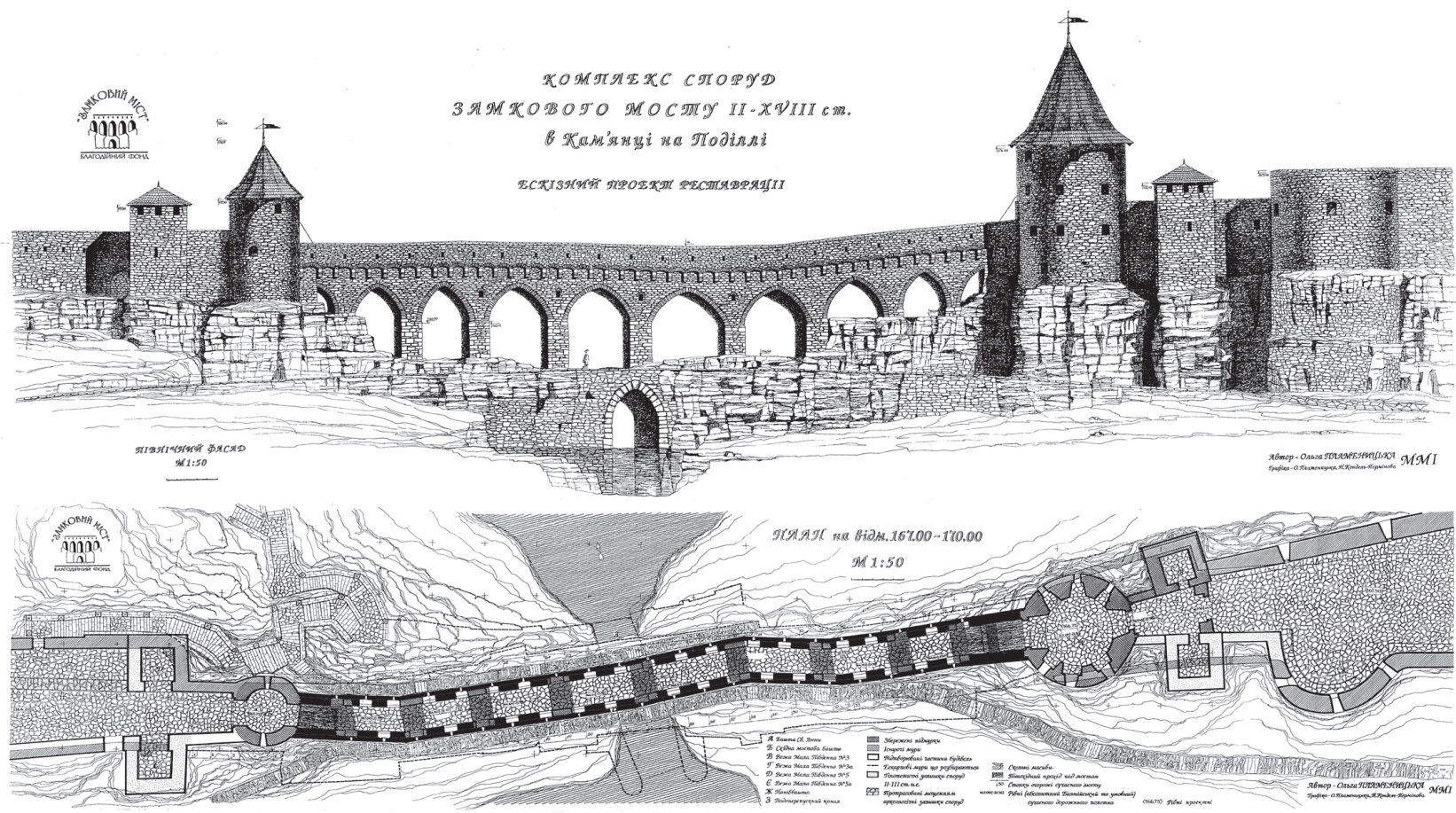

Іл. 12. Замковий міст у Кам'янці-Подільському.

Проект реставрації на період II ст. - кін. XVI ст. Автор проекту О. Пламеницька, графіка автора 
фікаційних споруд і Замкового мосту в Кам'янці-Подільському, атрибуція яких сягає епохи Траянових війн, можемо припустити, що римські легіони перейшли Дністер і контролювали території його лівого берега, де, за повідомленнями авторів XVII ст., були розміщені римські військові з'єднання і де знаходять численні дипломи римських легіонерів. Отже, розрізнені факти укладаються в логічну історичну концепцію, яка поступово наповнюється деталями.

Теоретично припустивши можливість іншої атрибуції зображення мосту на рельєфі № XCIX Траянової колони, ми порівняли його з давнім ядром Замкового мосту у Кам'янці-Подільському і не можемо не констатувати значну подібність їхньої архітектурно-конструктивної структури. Так, обидва мости:

- з'єднують архітектурні комплекси оборонного характеру та міського типу;

- становлять п'ятипрогінну споруду на кам'яних пілонах;
- мають змішану конструкцію: муровані пілони та дерев'яну верхню частину;

- збігаються за масштабом і розміром прогонів.

Це дає підстави використати зображення мосту на рельєфі № XCIX у ролі архітектурноконструктивного аналогу для відтворення вигляду Замкового мосту на період початку II століття нашої ери (iл. 11) з застереженням можливості майбутніх уточнень і коректив при подальших дослідженнях, які стануть можливими при реалізації проекту реставрації Замкового мосту (iл. 12).

Перспективи подальших досліджень. Отримані висновки дозволяють не лише скоригувати наші знання щодо історії окремого регіону Поділля, але дають підстави ставити питання ширше - про перегляд ролі Середнього Подністер'я в історії України як контактної зони на межі праслов'янського та пізньоантичного світу в перші століття нашої ери.

\section{Цитовані праці}

Данілов, I. "Uti possidetis. Про римлян, міст і не тільки (в контексті військової історії Кам’янця)". Пам'ятки України: Історія та культура 3-4 (2000): 135-140. Друк.

Ерофалов, Б. Римский Киев, или Castrum Azagarium на Киево-Подоле. Киев: А + С, 2019. Печать.

Климовский, С. И. Где, когда и почему возник Киев. Киев, 2013. Печать.

Кучера, М. «“Траянові” вали Середнього Подністров’я». Археологія 4 (1992): 42-55. Друк.

Левада, М. "Могильник Черепашинці: Спроба архівної реконструкції досліджень археологічної пам'ятки”. Пам'ятки України: Історія та культура 4 (2003): 12-19. Друк.

Логвин, Г. Н. “Початковий період давньоруської архітектури”. Мистецтво і сучасність: Зб. наук. праць. Київ: Наукова думка, 1980. 110-128. Друк.

Моммзен, Т. История Рима. Т. 5. Москва, 1949. Печать.

Надвірняк, О. В., О. Г. Погорілець. “Штрихи до історіографії питання римської присутності в межиріччі Верхнього і Середнього Подністров'я та Південного Побужжя в першій третині I тис. н. е.”. Хмельницькі краєзнавчі студіі: Наук.-краєзнав. зб. 13 (2018): 158-170. Друк.

Надвірняк, О. В., О. Г. Погорілець, та О. О. Надвірняк. "Римські військові дипломи на території Південно-Східної Європи”. OIUM. Черняхівська культура 5 (2016): 170-185. Друк.

Никитенко, Н. Н. Собор Святой Софии в Киеве. Москва, 2008. Печать.

Пламеницкая, О. “Исследования Каменца-Подольского над Днестром (к вопросу атрибуции моста на рельефе колонны Траяна в Риме". Реставрація, реконструкція, урбоекологія: Матеріали щорічного міжнародного симпозіуму RUR'98. Одеса; Білгород-Дністровський, 1998. 52-55. Печать.

Пламеницкая, О. “Крепость Каменец in statu nascendi”. Revista ARTA. Serie nouă. Vol. XXIV, nr. 1. Chișinău, 2015. 25-35. Druk.

Пламеницкая, O. "Casus pontis". ARTA. col. red.: Mariana Şlapac (red.-şef). Vol. XXVIII, nr. 1. Chişinău, 2019. Druk.

Пламеницкая, О. А. “Особенности средневековой застройки центра Каменца-Подольского”. Архитектурное наследство 33 (1985): 52-61. Печать.

Пламеницька, Є., О. Пламеницька. "Нова концепція формування системи фортифікацій Кам’янцяПодільського в аспекті визначення віку міста”. Фортифікація України. Міжнародна конференція з проблем охорони фортифікаційних споруд в Україні: Матеріали. Кам’янець-Подільський, 1993. 22-24. Друк. 
Пламеницька, E., О. Пламеницька. “Фортечний міст Кам’янця-Подільського: хронологічна і типологічна атрибуція”. Архітектурна спадщина України 2 (1995): 21-33. Друк.

Пламеницька, О. “До питання генези Кам'янець-Подільського Замкового мосту: Репліка з приводу атрибуції мосту Аполлодора на Колоні Траяна в Римі”. Теорія та історія архітектури: Збірник праць на честь Г. Н. Логвина 3 (1998): 108-117. Друк.

Пламеницька, О. “До питання методики дослідження стадіальності розвитку архітектурно-урбаністичних утворень (архітектурна петрографія як метод верифікації будівельної періодизації об’єктів Кам'янця-Подільського)". Сучасні проблеми дослідження, реставрації та збереження культурної спадщини VI (2009): 255-268. Друк.

Пламеницька, О. “Княжа доба як етап модернізації укріплень Кам'янця-Подільського (до проблеми стадіального розвитку міста-фортеці)”. Українська академія мистецтва: Дослідн. та наук.метод. пр. 23 (2014): 70-90. Друк.

Пламеницька, О. Castrum Caтепесеnsis. Фортеия Кам’янець (пізньоантичний - ранньомодерний час). Кам'янець-Подільський, 2012. Друк.

Пламеницька, О., Є. Пламеницька. “Кам'янець-Подільський - місто на периферії Римської імперії. Найдавніша урбаністична структура і фортифікаціі”. Пам’ятки України: Історія та культура 4 (1999): 1-80. Друк.

Письма Плиния Младшего. Кн. 8. Изд. подгот. М. Е. Сергеенко, А. И. Доватур. Москва, 1982. Печать.

Рубцов, С. М. Легионы Рима на Нижнем Дунае: Военная история римско-дакийских войн (конеи Iначало II века н. э.). Москва: Филоматис, 2003. Печать.

Шуази, О. История архитектуры. Т. 1. Москва, 1906. Печать.

Ammiani Marcellini. Rerum gestarum qui de XXXI supersunt, libri XVIII / ope MSS. codicum emendati ab Henrico Valesio, \& auctoribus adnotationibus illustrati. With: Fr. Lindenbrogi J. C. auctoriores Observationes in Ammianum Marcellinum... 1681

Antoni, J. Zameczki podolskie na kresach multańskich. T. II. Warszawa, 1880. Druk.

Bernacka-Lubańska, M. The Roman and the early-byzantine fortifications of Lower Moesia and Northern Thrace. Wrocław; Warszawa; Kraków, Ossolineum, 1982. Druk.

Cellarius, A. Regni Poloniae, Magnique ducatus Lithuaniae, omnimque regionum iuri Polonico subiectorum novissima descriptio, urbium potissimarum icones elegantissimas et delimitationem huius regni geographicam oculis subiieciens studio. Amsterdam, 1659. Druk.

Cichorius, C. Die reliefs der Trajanssäule: Die reliefs des zweiten Dakischen Krieges. Bd. III. Berlin: Reimer, 1896. Druk.

Cyaneae oder die am Bosphoro Thracico, Ligende hohe Stein-Klippen. Augsburg, 1687. Druk.

Davies, G. A. T. "Topography and the Trajan Column". Journal of Roman Studies X (1920): 1-28. Druk.

Dio's Roman History with an English translation by E. Cary, PhD. Vol. VIII. London: William Heinemann; New York: G. P. Putnam's Sons, 1925. Druk.

Găzdac, C., Alföldy-Găzdac, Á., Neagoe, M., Neagoe, O. Drobeta. The never abandoned city of Roman Dacia. Cluj-Napoca, 2015. Druk.

Gazzola, P. Ponti Romani. Firenze: Leo Plschki, 1963. Druk.

Karović, G., Mihajlović, D., Vučković, D. "Trajan's bridge over the Danube. The current results of underwater archaeological research". Proceedings of the 13 th Annual Meeting of the European Association of Archaeologists, Zadar, Croatia, septembar 2007, Session: Underwater Archaeology. Zagreb, 2008. 281-289. Druk.

Liske, X. Cudzodziemcy w Polsce. L. Nakier. U. Werdum. J. Bernoulli. J. E. Biester. J. J. Kausch. We Lwowie, 1876. Druk.

Nemeti, S. "The reliefs of Trajan's Column and Dio's text. The first Dacian war and imperial propaganda". Acta Musei Napocensis 53/I (2016): 137-150. Druk.

Okoń, P. "Czy most w Kamieńcu Podolskim jest budowlą rzymska??" Conservatio Aeterna Creatio Est: Seminarium z okazji 50-lecia pracy w ochronie i konserwacji zabytków Profesira Tadeusza Polaka. Kielce, 1998. 79-88. Druk.

Opyrchał, L. Drukowane plany i grafiki oraz medale z wizerunkiem twierdzy Kamieniec Podolski. Kraków, 2016. Druk.

Plamenytska, O., E. Plamenytska. "Daco-Roman Period in the History of Kamianets-Podilsky: Toward an Understanding of the Problem". 2nd International Conference "Problems and Methods in Historical Arhaeology”. Abstracts. Toronto-Lviv, 1992. 26-27. Druk. 
Płamienicka, O., J. Rymsza. "Kamyanets Podilsky in Roman times”. International Conference "The protection and management of Central and Eastern European Cities inscribed and nominated to the World Heritage List UNESCO. Warszawa, 1997. Druk.

Płamienicka, O. A., E. M. Płamienicka. "Most Zamkowy w Kamieńcu Podolskim: Na marginesie badań Kolumny Trajana w Rzymie". Kwartalnik Architektury i Urbanistyki 3 (1998): 183-207. Druk.

Plamenytska, O. "Recenti sviluppi degli studi sulle origini della cultura urbanistica e delle fortificazioni Ucraine nel periodo delle guerre di Traiano". Fondazzione Cassamarca. Conferenca Internazionale “Umanesimo Latino in Ucraina”: Leopoli, Casa della Scienza, 8 giugno 2002. Treviso: Fondazione Cassamarca, 2004. 59-66. Druk.

Ptolemeai, Claudii. Geographia e codicibus recognovit, prolegomenis, annotatione indicibus, tabulus instruxit. V. I. Carolus Mullerus. Parisiis, 1883. Druk.

Rymsza, J. "Most z kolumny Trajana nie został wybudowany na Dunaju”. Biuletyn informacyjny PKN ICOMOS 4 (35) (2016): 32-38. Druk.

Salmon, E. T. "Trajan's Conquest of Dacia". Transactions and Proceeding of the American Philological Association. Vol. 67. 1936. 83-105. Druk.

Šimić-Kanaet, Z. "Vessels, baskets and barrels of Trajan Column". Traian and the Danubian Provinces. The political, economic and religious life in the Danubian Provinces. 4th International Conference. ZagrebCroatia, 2017. Druk.

Stephenson, J. W. "The Column of Trajan in the light of ancient cartography and geography". Journal of Historical Geography 40 April (2013): 79-93. Druk.

Traian's, Bridge. Revitalization programme. Kladovo, 2011. Druk.

Tudor, D. Drobeta. Bucureşti, 1965. Druk.

Tudor, D. Podurile romane de la Dunărea de Jos. Bucureşti, 1971. Druk.

\section{References}

Danilov, I. "Uti possidetis. Pro rymlian, mist i ne tilky (v konteksti viiskovoi istorii Kamiantsia)". Pamiatky Ukrainy: Istoriia ta kultura 3-4 (2000): 135-140. Druk.

Erofalov, B. Rimskiy Kiev ili Sastrum Azagarium na Kievo-Podole. Kiev: A+C, 2019. Pechat.

Klimovskiy, S. I. Gde, kogda i pochemu voznik Kiev. Kiev: 2013. Pechat.

Kuchera, M. "Traianovi” valy Serednoho Podnistrovia". Arkheolohiia 4 (1992): 42-55. Druk.

Levada, M. "Mohylnyk Cherepashyntsi: Sproba arkhivnoi rekonstruktsii doslidzhen arkheolohichnoi pamiatky". Pamiatky Ukrainy: Istoriia ta kultura 4 (2003): 12-19. Druk.

Lohvyn, H. N. "Pochatkovyi period davnoruskoi arkhitektury". Mystetstvo i suchasnist: Zb. nauk. prats. Kyiv: Naukova dumka, 1980. 110-128. Druk.

Mommzen, T. Istoriya Rima. T. 5. Moskva, 1949. Pechat.

Nadvirniak, O. V., Pohorilets O. H. "Shtrykhy do istoriohrafii pytannia rymskoi prysutnosti v mezhyrichchi Verkhnoho i Serednoho Podnistrovia ta Pivdennoho Pobuzhzhia v pershii tretyni I tys. n.e.”. Khmelnytski kraieznavchi studii. Naukovo-kraieznav. zb. 13 (2018): 158-170. Druk.

Nadvirniak, O. V., Pohorilets O. H., Nadvirniak O. O. "Rymski viiskovi dyplomy na terytorii PivdennoSkhidnoi Yevropy". OIUM 5 (2016): 170-185. Druk.

Nikitenko, N. N. Sobor Svyatoy Sofii v Kieve. Moskva, 2008. Pechat.

Plamenitskaya, O. "Issledovaniya Kamentsa-Podolskogo nad Dnestrom (k voprosu atributsii mosta na relefe kolonnyi Trayana v Rime". Restavratsiia, rekonstruktsiia, urboekolohiia: materialy shchorichnoho mizhnarodnoho sympoziumu RUR98. Odesa - Bilhorod-Dnistrovskyi, 1998. 52-55. Druk.

Plamenitskaya, O. "Krepost Kamenets in statu nascendi". Revista ARTA. Serie nouă. Vol. XXIV, nr. 1, Chișinău, 2015. 25-35. Druk.

Plamenitskaya, O. "Casus pontis”. ARTA. col. red.: Mariana Şlapac (red.-şef). Vol. XXVIII, nr. 1. Chişinău, 2019. Druk.

Plamenitskaya, O. A. "Osobennosti srednevekovoy zastroyki tsentra Kamentsa-Podolskogo". Arhitekturnoe nasledstvo. 33 (1985): 52-61. Pechat.

Plamenytska, Ye., Plamenytska, O. "Nova kontseptsiia formuvannia systemy fortyfikatsii Kamiantsia-Podilskoho v aspekti vyznachennia viku mista". Fortyfikatsiia Ukrainy. Mizhnarodna konferentsiia z problem okhorony fortyfikatsiinykh sporud v Ukraini: Materialy. Kamianets-Podilskyi, 1993. 22-24. Druk.

Plamenytska, Ye., Plamenytska, O. "Fortechnyi mist Kamiantsia-Podilskoho: khronolohichna i typolohichna atrybutsiia". Arkhitekturna spadshchyna Ukrainy. 2 (1995): 21-33. Druk. 
Plamenytska, O. "Do pytannia genezy Kamianets-Podilskoho Zamkovoho mostu: Replika z pryvodu atrybutsii mostu Apollodora na Koloni Traiana v Rymi”. Teoriia ta istoriia arkhitektury: Zbirnyk prats na chest H. N. Lohvyna 3 (1998): 108-117. Druk.

Plamenytska, O. "Do pytannia metodyky doslidzhennia stadialnosti rozvytku arkhitekturno-urbanistychnykh utvoren (arkhitekturna petrohrafiia yak metod veryfikatsii budivelnoi periodyzatsii obiektiv Kamiantsia-Podilskoho)". Suchasni problemy doslidzhennia, restavratsii ta zberezhennia kulturnoi spadshchyny VI (2009): 255-268. Druk.

Plamenytska, O. "Kniazha doba yak etap modernizatsii ukriplen Kamiantsia-Podilskoho (do problemy stadialnoho rozvytku mista-fortetsi)". Ukrainska akademiia mystetstva. Doslidnytski ta naukovo-metodychni pratsi. 23 (2014): 70-90. Druk.

Plamenytska, O. Castrum Camenecensis. Fortetsia Kamianets (piznoantychnyi - rannomodernyi chas). Kamianets-Podilskyi, 2012. Druk.

Plamenytska, O., Plamenytska, Ye. "Kamianets-Podilskyi - misto na peryferii Rymskoi imperii. Naidavnisha urbanistychna struktura i fortyfikatsii”. Pamiatky Ukrainy: Istoriia ta kultura 4 (1999): 1-80. Druk.

Pisma Pliniya Mladshego: Kn. 8. Izd. podgot. M. E. Sergeenko, A. I. Dovatur. Moskva, 1982. Pechat.

Rubtsov, S. M. Legionyi Rima na Nizhnem Dunae: Voennaya istoriya rimsko-dakiyskih voyn (konets Inachalo II veka n.e.). Moskva: Filomatis, 2003. Pechat.

Shuazi, O. Istoriya arhitekturyi. T.1. Moskva, 1906. Pechat.

Ammiani Marcellini. Rerum gestarum qui de XXXI supersunt, libri XVIII / ope MSS. codicum emendati ab Henrico Valesio, \& auctoribus adnotationibus illustrati. With: Fr. Lindenbrogi J. C. auctoriores Observationes in Ammianum Marcellinum... 1681. Druk.

Antoni, J. Zameczki podolskie na kresach multańskich. T. II. Warszawa, 1880. Druk.

Bernacka-Lubańska, M. The Roman and the early-byzantine fortifications of Lower Moesia and Northern Thrace. Wrocław-Warszawa-Kraków, Ossolineum, 1982. Druk.

Cellarius, A. Regni Poloniae, Magnique ducatus Lithuaniae, omnimque regionum iuri Polonico subiectorum novissima descriptio, urbium potissimarum icones elegantissimas et delimitationem huius regni geographicam oculis subiieciens studio. Amsterdam, 1659. Druk.

Cichorius, C. Die reliefs der Trajanssäule: Die reliefs des zweiten Dakischen Krieges. Bd. III. Berlin: Reimer, 1896. Druk.

Cyaneae oder die am Bosphoro Thracico, Ligende hohe Stein-Klippen. Augsburg, 1687. Druk.

Davies, G. A. T. "Topography and the Trajan Column”. Journal of Roman Studies. X 1920: 1-28. Druk.

Dio's Roman History with an English translation by E.Cary, PhD. Vol. VIII. London: William Heinemann, New York: G. P. Putnam's Sons, 1925. Druk.

Găzdac, C., Alföldy-Găzdac, Á., Neagoe, M., Neagoe, O. Drobeta. The never abandoned city of Roman Dacia. Cluj-Napoca, 2015. Druk.

Gazzola, P. Ponti Romani. Firenze: Leo Plschki, 1963. Druk.

Karović, G., Mihajlović, D., Vučković, D. "Trajan's bridge over the Danube. The current results of underwater archaeological research". Proceedings of the 13 th Annual Meeting of the European Association of Archaeologists, Zadar, Croatia, septembar 2007, Session: Underwater Archaeology. Zagreb, 2008. 281-289. Druk.

Liske, X. Cudzodziemcy w Polsce. L. Nakier. U. Werdum. J. Bernoulli. J. E. Biester. J. J. Kausch. We Lwowie, 1876. Druk.

Nemeti, S. "The reliefs of Trajan's Column and Dio's text. The first Dacian war and imperial propaganda”. Acta Musei Napocensis, 53/I (2016): 137-150. Druk.

Okoń, P. "Czy most w Kamieńcu Podolskim jest budowlą rzymska??" Conservatio Aeterna Creatio Est: Seminarium zokazji 50-lecia pracy w ochronie i konserwacji zabytków Profesira Tadeusza Polaka. Kielce, 1998. 79-88. Druk.

Opyrchał, L. Drukowane plany I grafiki oraz medale z wizerunkiem twierdzy Kamieniec Podolski. Kraków, 2016. Druk.

Plamenytska, O., Plamenytska, E. "Daco-Roman Period in the History of Kamianets-Podilsky: Toward an Understanding of the Problem". 2nd International Conference "Problems and Methods in Historical Arhaeology”. Abstracts. Toronto-Lviv, 1992. 26-27. Druk.

Płamienicka, O., Rymsza, J. Kamyanets Podilsky in Roman times. International Conference "The protection and management of Central and Eastern European Cities inscribed and nominated to the World Heritage List UNESCO. Warszawa, 1997. Druk. 
Płamienicka, O. A., Płamienicka, E. M. "Most Zamkowy w Kamieńcu Podolskim: Na marginesie badań Kolumny Trajana w Rzymie". Kwartalnik Architektury i Urbanistyki 3 (1998): 183-207. Druk.

Plamenytska, O. "Recenti sviluppi degli studi sulle origini della cultura urbanistica e delle fortificazioni Ucraine nel periodo delle guerre di Traiano”. Fondazzione Cassamarca. Conferenca Internazionale "Umanesimo Latino in Ucraina”: Leopoli, Casa della Scienza, 8 giugno 2002. Treviso: Fondazione Cassamarca, 2004. 59-66. Druk.

Ptolemeai, Claudii. Geographia e codicibus recognovit, prolegomenis, annotatione indicibus, tabulus instruxit. V. I. Carolus Mullerus. Parisiis, 1883. Druk.

Rymsza, J. "Most z kolumny Trajana nie został wybudowany na Dunaju”. Biuletyn informacyjny PKN ICOMOS 4 (35) (2016): 32-38. Druk.

Salmon, E. T. "Trajan's Conquest of Dacia”. Transactions and Proceeding of the American Philological Association. Vol. 67. 1936. 83-105. Druk.

Šimić-Kanaet, Z. "Vessels, baskets and barrels of Trajan Column". Traian and the Danubian Provinces. The political, economic and religious life in the Danubian Provinces. 4th International Conference. Zagreb Croatia, 2017. Druk.

Stephenson, J. W. "The Column of Trajan in the light of ancient cartography and geography". Journal of Historical Geography 40 April (2013): 79-93. Druk.

Traian's, Bridge. Revitalization programme. Kladovo, 2011. Druk.

Tudor, D. Drobeta. Bucureşti, 1965. Druk.

Tudor, D. Podurile romane de la Dunărea de Jos. Bucureşti, 1971. Druk.

Подано до редакції 02.06.2019

Рецензенти:

Шлапак М. О. - доктор мистецтвознавства, член-кореспондент Академії наук Молдови;

Пучков А. О. - доктор мистецтвознавства, професор. 